\title{
Explaining Community Interest in Choosing Transjakarta as Daily - Day Transportation (Case Study on Corridor XIII of the Ciledug Route - Blok M)
}

\author{
Iskandar Muda Pulungan ${ }^{1}$, \\ Mercubuana University, Jakarta
}

\author{
Dr. Didik J. Rachbini \\ Mercubuana University, Jakarta
}

\author{
Dr. Endi Rekarti, SE.,M.E ${ }^{3}$ \\ Mercubuana University, Jakarta
}

\begin{abstract}
This study aims to determine the effect of service quality, tariffs, facilities, promotion, and behavior towards civil intention in choosing Transjakarta as daily transportation. This research uses quantitative methods, and a sample of 161 respondents who are usual passengers of Transjakarta thirteenth route Ciledug - M. Block By using convenience method and The data obtained were analyzed by SEM-LISREL application.
\end{abstract}

The results of this study show there is an effect between service quality towards behavior, tariff towards behavior, facility towards behavior, promotion towards behavior, behavior towards intention, service quality towards intention, tariff towards intention, facility towards intention, and promotion towards intention.

Keywords:- Service Quality, Tariff, Facility, Promotion, Behavior, Intention.

\section{INTRODUCTION}

Indonesia is the fourth most populous country in the world, with a population of 270 million based on 2018 data. Jakarta, as its capital, is the most populous city in Indonesia with a density of 15,500 thousand people / km2 (Wikipedia, 2018). . Congestion is a situation or situation that is stuck or even stopped due to the large number of vehicles exceeding the road capacity. Congestion usually occurs in big cities, especially if the amount of public transportation is not balanced with the needs of roads and population density.

According to Mustikarani and Suherdiyanto (2016), traffic congestion is caused by an imbalance between the number of residents and the number of vehicles that is increasing from year to year with the number of road segments in that place.

Adding road sections, is not a solution to break Jakarta's traffic jams. It can actually increase congestion in the capital, because it will increase the number of vehicles that cross the road. There is no evidence that the addition of roads to reduce congestion.

Based on Inrix Global Traffic Scorecard data (2017), Indonesia is ranked 2nd with 51 hours of traffic jams. While the first place is in Thailand which has the highest 56 hour traffic jam compared to other countries. In addition, the number of vehicles that continues to increase from year to year has resulted in increasingly uncontrolled traffic density. The number of vehicles is increasing every time, due to the increasing purchasing power of the people and the ease of owning a private vehicle with easier credit payments. The number of vehicles in Jakarta is dominated by motorcycles $(68 \%)$ which are majority owned by private users. Whereas Bus itself which is generally used as public transportation only accounts for $3 \%$. According to analysts, there are two factors which are the main causes of the high density of vehicles on the road. First, poor countries have a low percentage of car ownership. For example, Bangladesh only has 13 registered cars per 1000 people, 30 in Nigeria and 44 in Pakistan. This amount is in that the number of developing countries could be more than 500 cars registered. Highest road densities with vehicles occur in developing countries such as Indonesia, Vietnam and Thailand. Indonesia has the highest, 200 vehicles per kilometer. Various attempts have been made by the Jakarta Government to overcome the problem of congestion. Both for public transportation and for private vehicles. One way to reduce traffic congestion in the capital is to make mass transportation, called Transjakarta. Transjakarta is the first Bus Rapid Transit (BRT) transportation system in Southeast and South Asia, which has been operating since 2004 in Jakarta, Indonesia. This system was designed based on the successful TransMilenio system in Bogota, Colombia. Transjakarta is a BRT system with the longest cross-border lane in the world (230.9 km), and has 243 BRT stations (formerly called bus stops) spread over 13 corridors (lanes), which initially operated from 05.00 - 22.00 WIB, and some corridors have been operating 24 hours . Research conducted by Eriksson (2011) found that to make private car users switch to public transportation, public transportation must appear attractive to the public, affordable fares, clear schedules and routes so that users can travel efficiently. Other than that, car users must have the perception that the cost of private use is much higher compared to using public transportation. So, they can switch from private transportation to public transportation.

Research conducted by Beirao and Cabral (2006) found the results that many people will move from public transportation to private transportation if public transportation cannot improve the quality of their services which will certainly have an impact on people's satisfaction with public transportation.

Research conducted by Ammarsyaf (2017) found the results that promotion influences the attitude of using Transjakarta as a daily public vehicle. Transjakarta's 
promotions such as freeing certain days, pamphlet notifications and staff who provide information clearly succeed in creating customer satisfaction. The two Transjakarta corridors with the most passengers are corridor I (23.9 Million) and Corridor IX (14.3 Million) throughout 2016. However, what will be the object of research this time is corridor XIII on the Ciledug - Blok M. route. Because of this route, is the newest route developed by Transjakarta. And officially began operating on November 12, 2020.

\section{LITERATURE REVIEW}

\section{A. Consumer behavior}

Consumer behavior is the behavior exhibited by consumers in searching for, buying, using, evaluating, and consuming products and services that they expect will satisfy their needs (Schiffman and Kanuk, 2010). Whereas The American Marketing Association defines consumer behavior as a dynamic interaction of influence and awareness, behavior, and the environment in which humans exchange aspects of their lives. In other words, consumer behavior includes thoughts and feelings experienced by humans and actions taken during the consumption process (Peter \& Olson, 2010).

According to Kotler and Armstrong (2012), there are several factors that influence consumer behavior, including psychological factors. The types of psychological factors include:

1. Motivation, is a need that is sufficiently stimulated to make someone look for satisfaction with his needs;

2. Perception, is the process by which a person chooses, organizes, and presents information to form a meaningful picture.

3. Learning, is a change in individual behavior that comes from experience; Beliefs, are one's descriptive thoughts about something, and attitudes, describe the relatively consistent judgments, feelings, and tendencies of a person for an object or idea.

\section{B. Social marketing}

Social Marketing or in the Indonesian language is called social marketing is an adaptation of marketing theories in the framework of designing a program to influence someone in changing their behavior voluntarily in order to improve the welfare of individuals and also the community in which the individual is a part of (Andreassen, 2009). In general, social marketing is not a science, but rather professional activities that depend on various scientific disciplines in order to create intervention programs to change human behavior (Smith, 2011).

Although social marketing uses the theory of commercial marketing in its application, the target to be achieved by social marketing is different from commercial marketing. If in commercial marketing, consumers are asked to buy a product, switch to another brand or talk about the company's advantages, then in social marketing consumers are asked to buy new behaviors that often the target audience does not realize that they have a problem and the new behavior is a solution from the problem.

\section{Interest}

a. According to Winkel (2009), interest is a rather settled tendency to feel attracted to certain fields and feel happy to be involved in that field. Meanwhile, according to Witherington (2003), interest is someone's awareness of an object, a person, a problem or a particular situation that has something to do with himself or is seen as something conscious.

b. Interest Dimensions and Indicators

According to Tamin (2000), factors that can influence the selection of public transportation can be grouped into three, namely;

$>$ Road users, the indicators are:

1 Availability or ownership of private vehicles; the higher the ownership of private vehicles the smaller the dependence on public transport.

2 Ownership of Driving License (SIM)

3 Household Structure (young couples, families with children, retirement, bachelors, etc.).

4 Income, the higher the income the greater the opportunity to use private vehicles.

5 Other factors, the need to use a car to work and the need to take school children.

\section{$>$ Movement, the indicators are:}

1 Purpose of Movement, the movement to the workplace in developed countries is usually easier by using public transportation because of the timeliness and level of service is very good and the cost is relatively cheap compared to private transport (cars). However, the opposite is true in developing countries; people still use private cars to work, even though they are more expensive - because of punctuality, comfort, and other things that cannot be met by public transport.

2 Time The occurrence of the Movement, if we want to travel at midnight, we definitely need a private vehicle because at that time public transportation is not or rarely operates.

3 Distance Travel, the further the journey, we tend to choose public transportation compared to private transportation. For example, to travel from Jakarta to Surabaya; even though we have private cars, we tend to use public transportation (planes, trains, or buses) because of the great distances.

c. Facilities, the indicators are:

1 Time Travel, waiting time at the bus stop, walking time to the bus stop, time while moving, and so on.

2 Transportation costs (tariffs, fuel costs, etc.).

3 Space availability and parking rates.

4 City or zone. That is, the distance from the city center and population density.

According to Kotler (2013), some notions of interest which are the indicator dimensionization in this study are;

a. Interest is considered as a 'trap' or an intermediary for motivational factors that influence behavior, 
b. Interest also indicates how far someone has the ability to try,

c. Interest shows the measurement of one's will, and

d. Interest is related to ongoing behavior.

Of the various opinions above that explain the various dimensions used to measure attitudes; then the dimension used for this research is based on Kotler's theory.

\section{Attitude}

Specifically, Thurstone (2007) formulates attitudes as a degree of positive and negative affect on a psychological object. La Pierre, defines attitude as a pattern of behavior, tendency, or anticipatory readiness, predisposition to adjust to social situations, or simple ways.

Factors that influence the formation of attitudes in each individual according to Azwar (2011) are as follows:

1 Personal Experience, is something that has been and is being experienced by someone to shape and influence their appreciation of social stimulus. Response will be one of the bases for forming an attitude. To be able to have experience related to objects. This appreciation will form a positive or negative attitude in the future.

2 The Influence of Others, is an important social component that influences attitudes.

3 Mass media, serves as a means of communication that has a major influence in the formation of people's opinions and beliefs. Although the influence of mass media is not as large as the effect of direct individual interaction, in forming attitudes, mass media also play a role because it is a form of negative information.

4 Emotion Factor, functions as a channel for frustration or transfer of the ego defense mechanism. Such an attitude can be a temporary attitude and soon pass once frustration has disappeared. However, attitudes can be more persistent and enduring.

According to the research of Sumarsono and Giyatno (2012), environmental attitudes are predispositions (general tendencies) that are learned or formed in responding consistently to the environment in the form of likes (positive) or dislikes (negative), which are based on three components, namely:

a. Cognitive Components (knowledge and perception of environmental problems),

b. Affective components (emotions or feelings for the environment), and

c. Conative component (tendency to behave or act on the environment).

Of the various opinions above that explain the various dimensions used to measure attitudes; then the dimensions used for this research are cognitive, affective, and conative components.

\section{E. Service quality}

Quality is a dynamic condition related to products, services, people, processes, environments that meet and exceed expectations (Goethe and Davis). According to Gronos, service is an activity or series of activities that are invisible (cannot be touched) that occur as a result of interactions between consumers and employees or other things provided by the service provider company.

Customer perceptions of service quality can be measured and evaluated through service quality dimensions as stated by Zeithaml, et al (2009); as follows:

1 Tangibles (display physical), covering the facility physical, employee appearance, equipment used and physical presentation.

2 Reliability (trustworthiness), namely the ability to provide the promised service that is reliable and appropriate.

3 Responsivens (responsiveness), namely the willingness or readiness of employees to provide services and help consumers.

4 Assurance (guarantee), covers knowledge, courtesy and the ability of employees to gain customer trust.

5 Empathy (care), namely the care and attention of the company individually to consumers.

According to De Vreye, in order to improve service quality, there are 7 dimensions and indicators that must be considered:

1 Self - Esteem (self-esteem), with indicators for developing service principles; place someone according to their expertise; establishing futuristic service assignments and guided by the success of tomorrow must be better than today.

2 Exeed - expectation (meet expectations), with indicators adjusting service standards; understanding customer desires; and service according to the officers' expectations.

3 Recovery (improvement), with indicators: consider complaints as opportunities, not problems; resolve customer complaints; gathering information about customer desires; service standard trials; and hear customer complaints.

4 Vision (foresight), with indicators: ideal planning for the future; make the most of technology; and provide services according to customer needs.

5 Improve (improvement), with indicators: continuous improvement adjusts to changes; involving subordinates in the preparation of the plan; non-material investment (training) to create a conducive environment; and the creation of responsive standards.

6 Care (attention), with indicators: compiling a service system that satisfies customers; maintain quality; apply appropriate service standards; and testing of service standards.

7 Empower (empowerment), with indicators: empowering employees / subordinates: learning from experience; and provide stimulation, recognition and appreciation.

\section{F. Rates}

According to Alma (2011), price is the value of an item expressed in money. Price is the amount of value exchanged by the customer to obtain a benefit for goods or services that can be owned or used by the function because in the eyes of the customer, price is an important attribute evaluated that doubles the non-financial social value that 
must be sacrificed and for companies the role of price can shape customer attitude.

According to Kotler and Armstrong (2012), there are four indicators which include price namely;

1 Affordability of prices Consumers can reach the price set by the company.

2 Suitability of prices and quality of goods and services Prices are often used as an indicator of quality for consumers. Often, people choose a higher price between two brands because they see a difference in quality. If prices are higher, people tend to assume that the quality is also better.

3 Price and benefit suitability The consumer decides to pay for a service, if the perceived benefit is greater or equal to what has been spent to get it. If consumers feel the benefits are smaller than the money spent, consumers will assume that the service is expensive and consumers will think twice about making a repeat purchase.

4 Price competitiveness Consumers often compare the price of a service with other services, in this case the expensive cheapness of the money spent is highly considered by consumers when they will pay for the service.

\section{G. Amenities}

According to Tjiptono (2012), facilities are physical resources that exist before a service can be offered to consumers. Facilities are all things that facilitate consumers in businesses engaged in services.

According to Nurcahyadi (2017), the dimensions of the facilities in this study are as follows:

\section{Security Facilities}

Emergency rescue facilities in danger, installed in an easily accessible location are equipped with information on how to use stickers, and at least include glass-breaking hammers, fire extinguishers, and automatic door knobs. The indicator, the number that works and must be in accordance with the conditions in $100 \%$ technically.

\section{Medical facility}

First aid kit available on the bus or at the bus stop. The indicator, the amount available in accordance with the standard, there are at least three types of vehicle.

\section{Leisure Facilities}

Passenger aids stand and adequate seating. The indicator is the number that functions and must be in accordance with the standard conditions $100 \%$ technically.

\section{H. Promotion}

Promotion is a form of marketing communication language which is a marketing activity that seeks to spread information, influence / persuade, and remind target markets for companies and their products to be willing to accept, buy and be loyal to the products or services offered by the companies concerned (Hurriyati, 2010).
In this study, the dimensions and indicators of promotion are the promotion mix. According to Kotler and Keller (2013), the promotion mix consists of five main tools, namely:

\section{Advertising}

Represents all non-personal presentations, promotion of ideas, promotion of products or services by certain paid sponsors.

\section{Sales Promotion}

Short-term incentives to encourage the desire to try or buy a product or service.

\section{Public Relations and Publicity}

Various programs to promote or protect the image of a company or its individual products.

\section{Personal Selling}

Direct interaction with prospective buyers or more to make a presentation, answer directly and accept orders.

\section{Direct Marketing}

The use of mail, telephone, facsimile, e-mail, and other non-personal communication devices to communicate with or get direct responses from certain customers and prospective customers.

\section{THEORETICAL FRAMEWORK}

The framework is a combination of theoretical arguments and is supported by empirical evidence or the results of previous research on the proposed research problem. The framework of thought is arranged based on the relationship between variables according to the theory used as a reference.

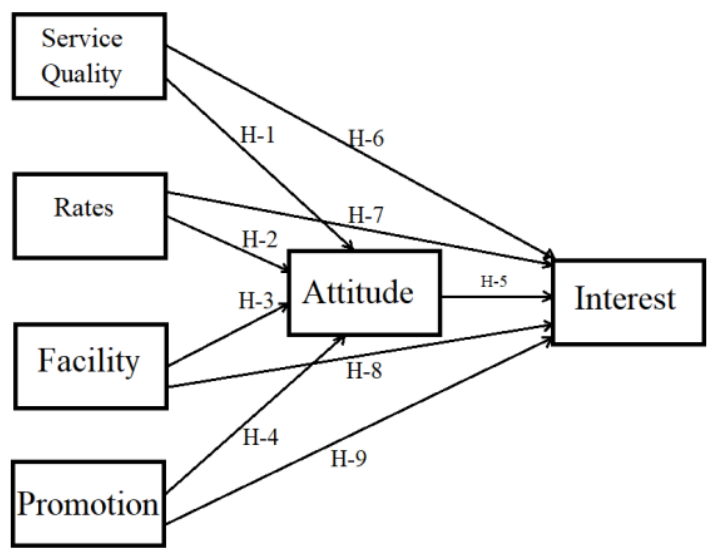

Fig 1

H1: Service Quality affects Attitude

$\mathrm{H} 2$ : Rates affect attitude

H3: Facility influences attitude

H4: Promotion influences attitude

H5: Attitude influences interest

H6: Service Quality influences Interest

H7: Rates affect interest 
H8: Facilities influence interest

H9: Promotion influences interest

\section{SAMPLES AND POPULATIONS}

The population in this study is the corridor 13 busway passengers (Ciledug - Blok M). The sampling technique in this study was to use purposive sampling. In this study, the authors determined 161 respondents. This amount is obtained by calculating the number of samples with the formula $7 \mathrm{x}$ the number of indicators (Heir, 1995), meaning that in this study the sample amounted $(7 \times 23=161)$.

\section{METHOD OF COLLECTING DATA}

Data collection methods are techniques or references that can be used to collect data. The way to collect data in this research is through field research. Data collection instruments used in the form of a questionnaire.

\section{DATA ANALYSIS METHOD}

The research method used in this study is quantitative analysis, meaning that the rating scale is used to state the weight between the relationship of one variable to another variable. To be able to find out the significance of influence between variables, the data is processed using SEM (Structural Equation Modeling) analysis method using Lisrel 9.2 software.

\section{RESULTS AND DISCUSSION}

\section{A. Descriptive Analysis of Respondents}

Of 161 respondents there were 67 respondents or $41.6 \%$ were male. Meanwhile, 94 respondents or $58.4 \%$ were female. So, the majority of respondents are women. Of 161 respondents, 26 respondents or $16.1 \%$ aged $<20$ years, 97 respondents or $60.2 \%$ aged 20 to 38 years, 22 respondents or $13.7 \%$ aged 39 to 50 years, and 16 respondents or $9.9 \%$ aged 51 to 69 years. So, the majority of respondents in this study were aged 20 to 38 years. Of 161 respondents there were 1 respondent $(0.6 \%)$ who had an elementary education, 11 respondents $(6.8 \%)$ who had a junior high school education, 58 respondents $(36.0 \%)$ senior high school or equivalent, 17 respondents $(10.6 \%)$ who had a Diploma (D1 / D2 / D3), and 74 respondents (46.0\%) who have Bachelor education (S1 / S2 / S3). So, the majority of respondents in this study were Bachelor graduates (S1 / S2 / $\mathrm{S} 3$ ). Of 161 respondents, the number of respondents who have expenses per month $<1$ million is 10 people $(6.2 \%)$, the number of respondents who have expenses per month 1-2 million as many as 34 people $(21.1 \%)$, the number of respondents who have expenses per month 2 - 3 million as many as 81 people $(50.3 \%)$, and the number of respondents who have expenses per month> 3 million as many as 36 people $(22.4 \%)$. So, the majority of respondents in this study had a monthly expenditure of 2-3 million. Of 161 respondents, 35 respondents or $21.7 \%$ were still students, 67 respondents or $41.6 \%$ were civil servants, and 59 respondents or $36.6 \%$ were private employees. So, the majority of respondents in this study work as civil servants.
Of 161 respondents, the number of respondents who have expenses per month $<1$ million is 10 people $(6.2 \%)$, the number of respondents who have expenses per month 1-2 million as many as 34 people $(21.1 \%)$, the number of respondents who have expenses per month 2 - 3 million as many as 81 people $(50.3 \%)$, and the number of respondents who have expenses per month> 3 million as many as 36 people $(22.4 \%)$. So, the majority of respondents in this study had a monthly expenditure of 2-3 million. Of 161 respondents, 35 respondents or $21.7 \%$ were still students, 67 respondents or $41.6 \%$ were civil servants, and 59 respondents or $36.6 \%$ were private employees. So, the majority of respondents in this study work as civil servants. Of 161 respondents, the number of respondents who have expenses per month $<1$ million is 10 people $(6.2 \%)$, the number of respondents who have expenses per month 1-2 million as many as 34 people $(21.1 \%)$, the number of respondents who have expenses per month 2 - 3 million as many as 81 people $(50.3 \%)$, and the number of respondents who have expenses per month> 3 million as many as 36 people $(22.4 \%)$. So, the majority of respondents in this study had a monthly expenditure of 2-3 million. Of 161 respondents, 35 respondents or $21.7 \%$ were still students, 67 respondents or $41.6 \%$ were civil servants, and 59 respondents or $36.6 \%$ were private employees. So, the majority of respondents in this study work as civil servants. 1 million as many as 10 people $(6.2 \%)$, the number of respondents who have expenses per month 1-2 million as many as 34 people $(21.1 \%)$, the number of respondents who have expenses per month 2-3 million as many as 81 people $(50.3 \%)$, and the number respondents who have monthly expenditure> 3 million are 36 people $(22.4 \%)$. So, the majority of respondents in this study had a monthly expenditure of 2-3 million. Of 161 respondents, 35 respondents or $21.7 \%$ were still students, 67 respondents or $41.6 \%$ were civil servants, and 59 respondents or $36.6 \%$ were private employees. So, the majority of respondents in this study work as civil servants. 1 million as many as 10 people $(6.2 \%)$, the number of respondents who have expenses per month 1-2 million as many as 34 people $(21.1 \%)$, the number of respondents who have expenses per month 2-3 million as many as 81 people $(50.3 \%)$, and the number respondents who have monthly expenditure> 3 million are 36 people $(22.4 \%)$. So, the majority of respondents in this study had a monthly expenditure of 2-3 million. Of 161 respondents, 35 respondents or $21.7 \%$ were still students, 67 respondents or $41.6 \%$ were civil servants, and 59 respondents or $36.6 \%$ were private employees. So, the majority of respondents in this study work as civil servants. the number of respondents who have expenditure per month of 2-3 million is 81 people $(50.3 \%)$, and the number of respondents who have expenses per month> 3 million is 36 people $(22.4 \%)$. So, the majority of respondents in this study had a monthly expenditure of 2-3 million. Of 161 respondents, 35 respondents or $21.7 \%$ were still students, 67 respondents or $41.6 \%$ were civil servants, and 59 respondents or $36.6 \%$ were private employees. So, the majority of respondents in this study work as civil servants. the number of respondents who have expenditure per month of 2-3 million is 81 people $(50.3 \%)$, and the number of respondents who have expenses per month> 3 
million is 36 people $(22.4 \%)$. So, the majority of respondents in this study had a monthly expenditure of 2-3 million. Of 161 respondents, 35 respondents or $21.7 \%$ were still students, 67 respondents or $41.6 \%$ were civil servants, and 59 respondents or $36.6 \%$ were private employees. So, the majority of respondents in this study work as civil servants. $6 \%$ work as civil servants, and 59 respondents or $36.6 \%$ work as private employees. So, the majority of respondents in this study work as civil servants. $6 \%$ work as civil servants, and 59 respondents or $36.6 \%$ work as private employees. So, the majority of respondents in this study work as civil servants.

\section{B. Descriptive Analysis Variable}

Descriptive test results of interest, showed that all indicators have the same most answers, namely agree with the number of respondents and with a different percentage, namely indicator 1 with the number of agree and strongly agree as many as 112 respondents $(69.6 \%)$, indicator 2 with the number of agree and very agree as many as 134 respondents $(82.6 \%)$, and indicator 3 with the number of agree and strongly agree as many as 137 respondents $(92.1 \%)$.

Attitude descriptive test results, showed that all indicators have the same most answers, namely agree with the number of respondents and with a different percentage, namely indicator 1 with the number of agree and strongly agree as much as 127 respondents (78.9\%), indicator 2 with the number of agreed and very agree as many as 124 respondents $(77 \%)$, indicator 3 with the number of agree and strongly agree as many as 118 respondents (73.3\%), and indicator 4 with the number of agree and strongly agree as many as 111 respondents $(69 \%)$

Descriptive test results of service quality, showed that all indicators have the same most answers, namely agreeing with the number of respondents and with a different percentage, namely indicator 1 with the number of agreeing and strongly agreeing with 115 respondents (68.4\%), indicator 2 with the number of agreeing and strongly agree as many as 113 respondents $(70.2 \%)$, indicator 3 with the number of agree and strongly agree as many as 131 respondents $(81.4 \%)$, indicator 4 with the number of agree and strongly agree as many as 110 respondents (68.3\%), indicator 5 with the number of agree and strongly agree as many as 113 respondents $(70.1 \%)$, indicator 6 with the amount of agree and strongly agree as much as 107 respondents $(66.5 \%)$, indicator 7 with the number of agree and strongly agree as many as 121 respondents $(75.1 \%)$, and indicator 8 with the number of agree and strongly agree as much 122 respondents $(75.8 \%)$.

Descriptive test results of the tariff, showed that all indicators have the same most answers, namely agreeing with the number of respondents and with a different percentage, namely indicator 1 with the number of agreeing and strongly agreeing to 106 respondents $(65.8 \%)$, indicator 2 with the number of agreeing and very agree as many as 112 respondents $(69.5 \%)$, and indicator 3 with the number of agree and strongly agree as many as 123 respondents $(76.4 \%)$.

Descriptive test results of the facility, showed that all indicators have the same most answers, namely agree with the number of respondents and with a different percentage, namely indicator 1 with the number of agree and strongly agree as many as 122 respondents $(75.7 \%)$, indicator 2 with the number of agreed and very agree as much as 112 respondents $(69.6 \%)$, indicator 3 with the number of agree and strongly agree as many as 120 respondents (75.5\%), indicator 4 with the number of agree and strongly agree as many as 100 respondents $(62.1 \%)$, indicator 5 with the number of agree and strongly agree as much 100 respondents $(62.2 \%)$, indicator 6 with the amount of agree and strongly agree as many as 120 respondents $(75.5 \%)$, indicator 7 with the number of agree and strongly agree as many as 114 respondents $(70.8 \%)$, and indicator 8 with the number of agree and strongly agree as much as 110 respondents $(68.3 \%)$.

The descriptive promotion test results show that all indicators have the same most answers, namely agreeing with the number of respondents and with a different percentage, namely indicator 1 with the number of agreeing and strongly agreeing to 116 respondents $(72.1 \%)$, indicator 2 with the number of agreeing and very agree as much as 112 respondents $(69.5 \%)$, and indicator 3 with the number of agree and strongly agree as many as 115 respondents $(65.3 \%)$

\section{Validity test}

The validity test uses the Factor Analysis model, which needs to be considered in this test is the value of Standardize Loading Factor (SLF) in the Anti Image table and the Extraction Value in the Communalitties table. Questions will be considered valid if the SLF and Exraction values are greater than 0.5 .

In this test 3 indicators were observed about the interests that have been tested, by getting the results of ChiSquare $=55.21, \mathrm{df}=20, \mathrm{P}$-Value $=0.00003$, RMSEA $=$ 0.066 . of the 4 observed indicators included in SEM, there are observable indicators that have a Standardize Loading Factor value $\geq 0.50$, i.e. S1 - S4, so that all models are observed to be valid

In this test 8 indicators were observed about the Quality of Service that has been tested, by getting the results of Chi-Square $=67.42, \mathrm{df}=20, \mathrm{P}$-Value $=0.00000$, RMSEA $=0.026$. of the 4 observed indicators included in SEM, there are observable indicators that have a Standardize Loading Factor value $\geq 0.50$, i.e. S1 - S4, so that all models are observed to be valid.

Of the 4 observed indicators included in the SEM, there are observable indicators that have a Standardize Loading Factor value $\geq 0.50$ ie, S1 - S4, so that all models are observed to be valid

Of the 4 observed indicators included in the SEM, there are observable indicators that have a Standardize 
Loading Factor value $\geq 0.50$ ie, S1 - S4, so that all models are observed to be valid

In this test 8 indicators were observed about the facilities that had been tested, by getting the results of ChiSquare $=56.21$, df $=20$, P-Value $=0.00003$, RMSEA $=$ 0.063 .

above of the 8 observed indicators included in SEM, there are observable indicators that have a Standardize Loading Factor value $\geq 0.50$ that is, F1 - F8, so that all models are observed to be valid.

In this test 3 indicators were observed about the promotion that had been tested, by getting the results of ChiSquare $=52.21$, df $=20$, P-Value $=0.00003$, RMSEA $=$ 0.023 .

In Figure 1 above of the 3 observed indicators included in SEM, there are observable indicators that have a Standardize Loading Factor value $\geq 0.50$, i.e. P1 - P3, so that all models are observed to be valid

\section{Reliability Test}

Reliability test shows the extent to which a measuring instrument that can provide relatively the same results if carried out measurements again on the same object.

The test is carried out by comparing the Cronbach Alpha.

\section{Interest}

( $\sum$ Standardized Loading) 2

$(0.61+0.51+0.71) 2=3.35$

$\sum$ Standardized Loading2

$0.612+0.512+0.712=1.14$

$\sum$ Measurement Error

$0.36+0.24+0.16=0.76$

From the above calculation it can be seen that the variable of interest has a $C R$ value of 0.70 and $V E>0.50$. Then the variable is declared reliable for use in research.

\section{Attitude}

( $\sum$ Standardized Loading) 2

$(0.78+0.71+0.79+0.73) 2=9.06$

$\sum$ Standardized Loading2

$0.782+0.712+0.792+0.732=2.27$

$\sum$ Measurement Error

$0.29+0.20+0.37+0.27=1.13$
From the above calculation it can be seen that the attitude variable has a $C R$ value $>0.70$ and $V E>0.50$. Then the variable is declared reliable for use in research. $(0.66+$ $0.62+0.58+0.72+0.69+0.65+0.65+0.58) 2=26.52$

$\sum$ Standardized Loading2

$0.662+0.622+0.582+0.722+0.692+0.652+0.652+$ $0.582=3.33$

$\sum$ Measurement Error

$0.36+0.21+0.26+0.48+0.32+0.38+0.37+0.37=2.75$

From the above calculation it can be seen that the service quality variable has a $\mathrm{CR}$ value $>0.70$ and $\mathrm{VE}>0.50$. Then the variable is declared reliable for use in research.

\section{Rates}

( $\sum$ Standardized Loading) 2

$(0.79+0.77+0.77) 2=5.43$

$\sum$ Standardized Loading2

$0.792+0.772+0.772=1.81$

$\sum$ Measurement Error

$0.38+0.21+0.21=0.80$

From the above calculation it can be seen that the tariff variable has a $C R$ value $>0.70$ and $V E>0.50$. Then the variable is declared reliable for use in research.

\section{Amenities}

( $\sum$ Standardized Loading) 2

$(0.71+0.68+0.74+0.70+0.74+0.73+0.73+0.73) 2=$ 33.18

$\sum$ Standardized Loading2

$0.712+0.682+0.742+0.702+0.742+0.732+0.732+$ $0.732=4.15$

$\sum$ Measurement Error

$0.39+0.23+0.35+0.21+0.36+0.36+0.36+0.47=2.73$

From the above calculation, it can be seen that the facility variable has a $\mathrm{CR}$ value $>0.70$ and $\mathrm{VE}>0.50$. Then the variable is declared reliable for use in research.

\section{Promotion}

$\left(\sum\right.$ Standardized Loading $) 2(0.92+0.66+0.74) 2=5.38$

$\sum$ Standardized Loading2

$0.922+0.662+0.742=1.83$

$\sum$ Measurement Error

$0.15+0.37+0.36=0.88$

From the above calculation it can be seen that the promotion variable has a CR value> 0.70 and $\mathrm{VE}>0.50$. Then the variable is declared reliable for use in research. 


\section{Structural Match Test Results (T-Value)}

\begin{tabular}{|c|c|c|c|c|}
\hline No. & Ukuran GOF & $\begin{array}{l}\text { Tingkat Target } \\
\text { Kecocokan }\end{array}$ & $\begin{array}{l}\text { Hasil } \\
\text { Estimasi }\end{array}$ & $\begin{array}{l}\text { Tingkat } \\
\text { Kecocokan }\end{array}$ \\
\hline 1 & $\begin{array}{l}\text { Root Mean Square Error of } \\
\text { Appoximation (RMSEA) P } \\
\text { (close Fit) }\end{array}$ & $\begin{array}{l}\text { RMSEA } \leq 0,08 \\
P \geq 0,50\end{array}$ & 0.066 & Good Fit \\
\hline 2 & Normed Fit Index(NFI) & $\mathrm{NFI} \geq 0,90$ & 0.96 & Good Fit \\
\hline 3 & $\begin{array}{l}\text { Non-Noormed Fit Index } \\
\text { (NNFI) }\end{array}$ & $\mathrm{NNFI} \geq 0,90$ & 0.97 & Good Fit \\
\hline 4 & $\begin{array}{l}\text { Comparative Fit Index } \\
\text { (CFI) }\end{array}$ & $\mathrm{CFI} \geq 0,90$ & 0.98 & Good Fit \\
\hline 5 & Incremental Fit Index (IFI) & $\mathrm{IFI} \geq 0,90$ & 0.98 & Good Fit \\
\hline 6 & Relative Fit Index (RFI) & $\mathrm{RFI} \geq 0,90$ & 0.96 & Good Fit \\
\hline 7 & Goodnees of Fit Index (GFI) & $\mathrm{GFI} \geq 0,90$ & 0.73 & Marginal Fit \\
\hline 8 & $\begin{array}{l}\text { Adjusted Goodness of Fit } \\
\text { Index (AGFI) }\end{array}$ & $\mathrm{AGFI} \geq 0,90$ & 0.84 & Marginal Fit \\
\hline
\end{tabular}

Table 1

Source: Lisrel 9.2

From the table it can be seen that the suitability value of the model shows a good value, meaning that the overall suitability value indicates good fit.

\section{Structural Model (Standardized Solution)}

To see the analysis in Figure 1, it is necessary to look at the previous test, the t-value test in Figure 2. The service quality variable has a significant effect on attitudes and interests with the largest Standardized Loading Factor value of 0.71 on the seventh indicator, viz.

"In Transjakarta, drugs and first aid kits are always available". That is, most respondents feel safe and helped if in an emergency.

\section{DISCUSSION}

\section{Analysis of the Effect of Service Quality on Attitude}

Based on table 1, it can be concluded that the service quality variable has a significant effect on attitude. The $t-$ value in this study was 6.51 greater than t-table; 1.96 . That is, the quality of service such as Transjakarta officers who are always friendly and always ready to help; availability of P3K; and the timeliness of departing and arriving makes the attitude of Transjakarta Bus passengers Koriodor I feel happy to use Transjakarta in every trip. The results of this hypothesis test, support the results of research conducted by Elfian and Ariwibowo (2018) which states that service quality has a significant effect on the attitude of satisfaction of Transjakarta passengers.

\section{Analysis of the Effect of Rates on Attitudes}

Based on table 1, it can be concluded that the variable variable has a significant effect on attitude. The t-value in this study was 7.43 greater than t-table; 1.96. This means that Transjakarta tariffs that are quite affordable make the attitude of Transjakarta Corridor I passengers feel happy using city facilities such as Transjakarta.

The results of this hypothesis test, support the results of research conducted by Malau, et al (2015) which states that the tariff has a significant effect on the ticket buying attitude of Trans Semarang passengers.

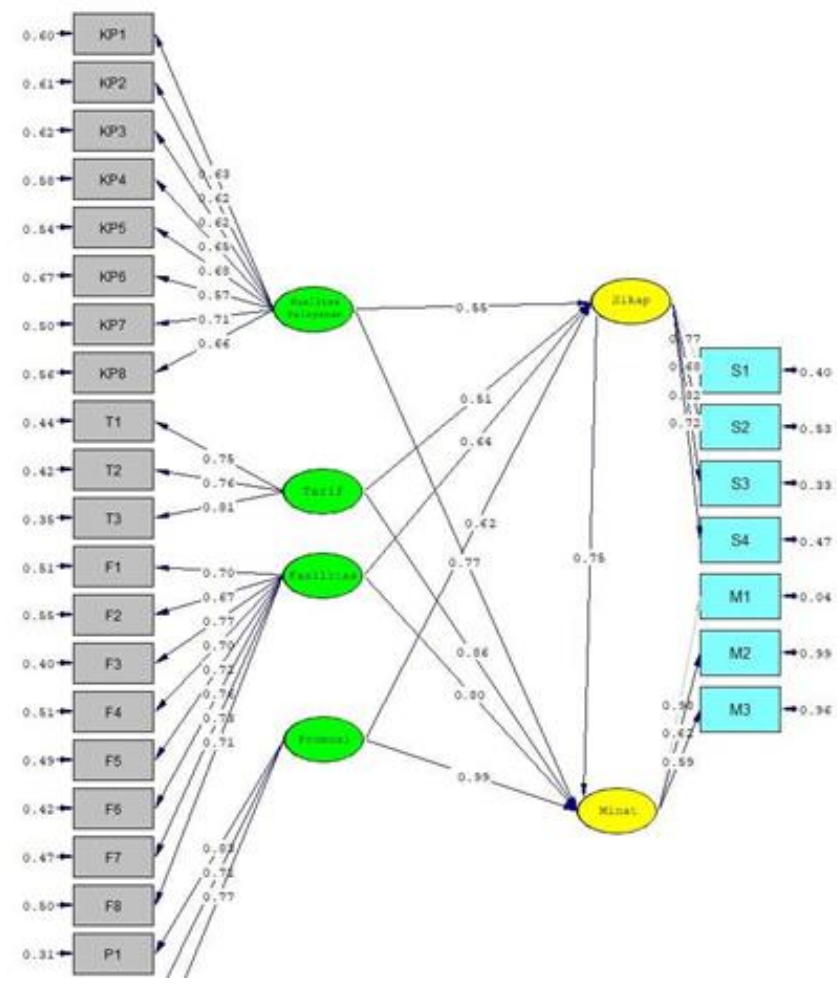

Fig 2

\section{Analysis of the Effect of Facilities on Attitudes}

Based on table 1, it can be concluded that the facility variable has a significant effect on attitude. The t-value in this study was 8.37 greater than t-table; 1.96. That is, Transjakarta facilities such as comfortable bus conditions, adequate waiting rooms, and access to bus stops which greatly facilitates passengers make their attitude feel appropriate to use Transjakarta as public transportation compared to other public transportation. The results of this hypothesis test, support the results of research conducted by Syufa'ati (2016) which states that the facility has a significant effect on consumer purchasing attitudes.

\section{Analysis of the Effect of Promotion on Attitude}

Based on table 1, it can be concluded that the promotion variable has a significant effect on attitude. The tvalue in this study was 4.48 greater than t-table; 1.96 . That is, Transjakarta advertisements that are interesting and easily understood by the public make their attitude interested in using Transjakarta. The results of this hypothesis test, support the results of research conducted by Malau, et al (2015) which states that promotion has a significant effect on the attitude of ticket purchases of Trans Semarang passengers.

\section{Analysis of the Effect of Attitude Towards Interest}

Based on table 1, it can be concluded that the attitude variable has a significant effect on interest. The t-value in this study was 6.74 greater than t-table; 1.96 . That is, the attitude of Transjakarta corridors I passengers who feel 
proud that Jakarta has Transjakarta makes them always use Transjakarta as a transportation need.

The results of this hypothesis test, support the results of research conducted by Rekarti, et al (2017) which states that attitudes significantly influence the purchase interest.

\section{$>$ Analysis of the Effect of Service Quality on Interest}

Based on table 1, it can be concluded that the service quality variable significantly influences interest. The t-value in this study was 6.77 greater than t-table; 1.96 . That is, the quality of service such as Transjakarta officers who are always friendly and always ready to help; availability of P3K; and punctual departure and arrival make Transjakarta Bus passengers Koriodor I always prioritize Transjakarta as the main transportation.

The results of this hypothesis test, support the results of research conducted by Nuryati (2014) which states that service quality has a significant effect on purchasing interest.

\section{$>$ Analysis of the Effect of Rates on Interest}

Based on table 1, it can be concluded that the variable variable has a significant effect on interest. The t-value in this study was 3.80 greater than t-table; 1.96. This means that Transjakarta tariffs that are in line with facilities and services make Transjakarta Corridor I passengers always prioritize Transjakarta as public transportation. The results of this hypothesis test, support the results of research conducted by Malau, et al (2015) which states that tariffs have a significant effect on the interest in purchasing tickets for Trans Semarang passengers.

\section{$>$ Analysis of the Effect of Facilities on Interest}

Based on table 1, it can be concluded that the facility variable significantly influences interest. The t-value in this study was 8.81 greater than t-table; 1.96. That is, Transjakarta facilities such as comfortable bus conditions, adequate waiting rooms, and access to bus stops which greatly facilitates the passengers make the people of Jakarta always prioritize Transjakarta as public transportation compared to other public transportation.

The results of this hypothesis test, support the results of research conducted by Syufa'ati (2016) which states that the facility has a significant effect on consumer purchasing interest.

\section{Analysis of the Effect of Promotion on Interests}

Based on table 1, it can be concluded that the promotion variable significantly influences interest. The tvalue in this study was 8.81 greater than t-table; 1.96 . This means that Transjakarta ads are attractive, easily understood by the public, and give a positive impression making them interested in using Transjakarta.

The results of this hypothesis test, support the results of research conducted by Malau, et al (2015) which states that promotion has a significant effect on the interest in purchasing tickets for Trans Semarang passengers.

\section{Analysis of Indirect Effects on Interests}

The direct effect of service quality on interest is 0.77 and the indirect effect of service quality on interest is 0.56 with a total effect of 1.33 . The direct effect of the rate on interest is 0.86 and the indirect effect of the tariff on interest is 0.38 with a total effect of 1.25 . The direct effect of the facility on interest is 0.80 and the indirect effect of the facility on interest is 0.48 with a total effect of 1.28 . Then, the direct effect of promotion on interest is 0.99 and the indirect effect on interest is 0.47 with a total effect of 1.45 .

The greatest total effect on interest is the promotion variable and service quality variable. Both of these variables provide a very dominant role in determining people's interest in using TransJakarta. The services provided are very good, such as punctuality of arrival and arrival, officers who are always alert and act quickly, and are always friendly. Promotions that are carried out by delivering messages that are easily understood by each of the community become a special attraction. Variable rates and promotions provide a significant and significant influence. That is, this is very effective for long-term and short-term (especially) strategies. Cheap rates and strategic promotions,

\section{CONCLUSION}

Based on the data analysis and discussion presented in the previous chapter, several research conclusions can be made as follows: attitude.

Service quality variable has a significant effect on

1. That is, the quality of service such as Transjakarta officers who are always friendly and always ready to help; availability of P3K; and the timeliness of departing and arriving makes the attitude of Transjakarta Bus passengers Koriodor I feel happy to use Transjakarta in every trip.

2. Tariff variable has a significant effect on attitude. This means that Transjakarta tariffs that are quite affordable make the attitude of Transjakarta Corridor I passengers feel happy using city facilities such as Transjakarta.

3. Facility variables significantly influence attitude. That is, Transjakarta facilities such as comfortable bus conditions, adequate waiting rooms, and access to bus stops which greatly facilitates passengers make their attitude feel appropriate to use Transjakarta as public transportation compared to other public transportation.

4. Promotional variables significantly influence attitude. That is, Transjakarta advertisements that are interesting and easily understood by the public make their attitude interested in using Transjakarta.

5. Attitude variable significantly influence interest. That is, the attitude of Transjakarta corridors I passengers who feel proud that Jakarta has Transjakarta makes them always use Transjakarta as a transportation need.

6. Service quality variable has a significant effect on interest. That is, the quality of service such as Transjakarta officers who are always friendly and always ready to help; availability of $\mathrm{P} 3 \mathrm{~K}$; and punctual departure and arrival make Transjakarta Bus passengers 
Koriodor I always prioritize Transjakarta as the main transportation.

7. Tariff variable significantly influences interest. This means that Transjakarta tariffs that are in line with facilities and services make Transjakarta Corridor I passengers always prioritize Transjakarta as public transportation.

8. Facility variables significantly influence interest. This means that Transjakarta facilities such as comfortable bus conditions, adequate waiting rooms, and access to bus stops that greatly facilitate passengers make the Jakarta people always prioritize Transjakarta as public transportation compared to other public transportation.

9. Promotional variables significantly influence interest. This means that Transjakarta ads are attractive, easily understood by the public, and give a positive impression making them interested in using Transjakarta.

10. The biggest total influence on interest is the promotion variable and service quality variable. Both of these variables provide a very dominant role in determining people's interest in using TransJakarta. The services provided are very good, such as punctuality of arrival and arrival, officers who are always alert and act quickly, and are always friendly. Promotion carried out by the delivery of messages that are easily understood by each community is the main attraction.

\section{RECOMMENDATIONS}

Advice for Companies;

\section{A. Service quality}

Suggestions that can be taken into consideration are that TransJakarta officials must always be alert and be prepared to provide assistance.

\section{B. Rates}

Suggestions that can be taken into consideration are the management organizing training to improve the standards of hospitality that should be.

\section{Amenities}

A suggestion that can be taken into consideration is that TransJakarta officers should remind each other both to passengers and fellow officers to maintain TransJakarta cleanliness.

\section{Promotion}

Suggestions that can be taken into consideration are to renew the existing advertising language, which is in accordance with current developments.

Suggestions that can be taken into consideration are the Transjakarta management to express their gratitude both directly and indirectly to every community who has chosen Transjakarta as their transportation, so that passengers will feel respected and valued so that they feel happy and tend to use Transjakarta again at later.

\section{E. Interest}

Suggestions that can be taken into consideration are that Transjakarta management should improve the quality of services and facilities so that passengers feel more comfortable using Transjakarta than using public or private vehicles.

\section{F. Operational Advice}

Technically, Transjakarta should add corridors that can touch the entire Jabodetabek area and add a fleet to meet the needs of people who want to use Transjakarta. In addition, Transjakarta must also cooperate with the government to prohibit the use of private vehicles in the protocol area, so that people are more encouraged to use public transportation, such as Transjakarta.

\section{G. Suggestions for further research}

For further research, it can be used as additional information and knowledge and can also be used as a reference for further research, such as this study by choosing public transportation as the research subject and the variables that the researchers studied. Then the sample under study can also be adjusted to the number of respondents who will be decided to become further research material. In addition, in subsequent studies can add variables such as lifestyle, total income, and personality (extrovert and introvert)

\section{REFERENCES}

[1]. Albertus, Vishnu Nugroho. 2010. Implementation of Personal Selling In Influence Against Purchasing Decisions of Honda Motorcycle Consumers at CV. Aceh Honda Motor Bandung. Indonesian Computer University.

[2]. Alma, Buchari. 2011. Marketing Management and Marketing Services. Revised Edition.Bandung:

[3]. Alfabeta.Andreasen, Alan. R. and Kotler, Philip. 2009. Strategic Marketing For Non-Proft Organizations 6th ed. Upper Saddle River, NJ: Prentice Hall.

[4]. Armstrong, Kotler. 2015. "Marketing an Introduving Prentice Hall Twelfth Edition", England: Perason Education, Inc.

[5]. Azwar S. 2011. Human Attitude: Theory and Measurement. Jakarta: Student Library.

[6]. Engel et al. 2010. Consumer Behavior. Sixth Edition, Volume 1. Jakarta: Binarupa Aksara.

[7]. Ghozali, Imam. 2013. Multivariate Analysis Application with SPSS Program. Seventh Edition. Diponegoro University Publisher Agency: Semarang.

[8]. Gilbert, David; et al. 2004. Retail Marketing Management. Second Edition.Prentice Hall.

[9]. Hair, Jr., Joseph F., et. al. (2011). Multivariate Data Analysis. Fifth Edition. New Jersey: PrenticeHall, Inc.

[10]. Herdianawati. 2012. Analysis of the Effect of Service Quality on Community Satisfaction of Transjakarta Busway Corridor 2 Users in the DKI Jakarta Regional Government. Journal of Masters in Management Vol. 1, No. 1, 49 - 78. ASMI Institute of Business and Multimedia. 
[11]. Hilgard. 2003. Motivation: Theory and Research. Belmong, California: Wads Publishing Company.

[12]. Holland. 2007. The Self - Directed Search. Toronto: The Guidance Center, University of Toronto.

[13]. Hurriyati, Ruth. 2010. Marketing Mix and Consumer Loyalty. Bandung: Alfabeta.

[14]. Kotler; Keller. 2013. Marketing Management: 14 Editon, New Jersey: Prentice Hall, Pearson Hall, Pearson Education, Inc.

[15]. Lupiyoadi, Rambat; Hamdani, A. 2006. Marketing Management Services. Second Edition. Jakarta: Salemba Empat.

[16]. Mursid, M. 2014. Marketing Management. Jakarta: Earth Literacy.

[17]. Notoatmodjo, S. 2007. Health Promotion and Behavioral Sciences. Jakarta: Rineka Cipta.

[18]. Peter J, Paul; Olson, Jerry C. 2010. Consumer Behavior and Marketing Strategy 9th ed. New York, USA: Mc Graw Hill.

[19]. Embrace it, Freddy. 2009. Creative Promotion Strategies and Case Analysis for Integrated Marketing Communication. Jakarta, PT Gramedia Pustaka Utama.

[20]. Rekarti, Endi; Hertina, Lilis. 2014. Some Factors That Influence the Interest in Buying Online on the Buying and Selling Site of Tokobagus.Com. Journal of Economic and Social Sciences, Volume 2, Nomr 3, 311 - 318, Mercu Buana University.

[21]. Rekarti, Endi; Meiwanto D., Caturida; Anah, Sri. 2017. Building Customer's Buying Interersts to Traditional Nuance Restaurants: A Model of Proposed Study. Mercu Buana University.

[22]. Saladin, Djaslim. 2012. Marketing Management Analysis, Planning, Implementation and Control. Third Edition. Bandung: CV. Linda Karya.

[23]. Schiffman, Leon G., \& Leslie Lazar Kanuk. 2010. Consumer Behavior. NJ: Prentice Hall, Inc.

[24]. Sitinjak JRT and Sugiarto. 2006. LISREL. Yogyakarta: Graha Science.

[25]. Smith, PR; Ze Zook. 2011. Marketing Communications: Integrating Offline and Online With Social Media. Great Britain: Ashford Color Press.

[26]. Solimun, et al. 2017. Multivariate Statistical Methods, Structural Equation Modeling (SEM), WarpPLS Approach. Malang: UB Press.

[27]. Sugiyono 2016. Educational Research Methods Quantitative, Qualitative, and R\&D Approaches. Alfabeta: Bandung

[28]. Suharyadi and Purwanto. 2011. Statistics for Modern Economics and Finance Edition 2. Jakarta: Four Salemba.

[29]. Suryabarata, Sumadi. 2011. Research Methodology. Jakarta: Raja Grafindo Persada.

[30]. Suratno; Rekarti, Endi; J. Rachbini, Didik. 2017. Role in Mediating the Effect of Environmental Knowledge and Price Perceptions on Green Purchases Intention of Organic Food Products. SWOT Journal, Vol. VII, No.2, Mercu Buana University.
[31]. Syufa'ati, Vivi Laili. 2016. Effect of Products, Location, and Facilities on Purchasing Decisions (Study on Maccadina Yogyakarta Consumers). Sunan Kalijaga State Islamic University.

[32]. Takeuchi, T; Nishio, C. 2000. The Qualitative Content of Television Advertising and Its Penetration: The Case in Japan. Marketing Intelligence \& Planning 18 (2).

[33]. Paul, Dialson, (2019). The Influence of Work Morale and Competence on Work Motivation and Its Implementation Against Work Productivity of PT. Sinar Metrindo Perkasa. Jakarta: Mercu Buana University

[34]. Tamin, Ofyar Z. 2000. Transportation Planning and Modeling. Bandung, Indonesia: ITB Publisher.

[35]. Thurstone, LL 2007. Attitudes can be measurd. American Journal of Socioloigy, 33, 529-54.

[36]. Tjiptono, Fandy; Chandra, Gregory. 2012. Strategic Marketing. Yogyakarta: ANDI.

[37]. Wijanto, Setyo Hari. 2008. Structural Equation Modeling with Liserl 8.8 Concepts and Tutorials. Graha Science.

[38]. Winkel, WS 2009. Teaching Psychology. Jakarta: Gramedia.

[39]. Witherington, Cart. 2003. Psychology of Purwanto Translation Education. Jakarta: Youth Rosda Karya.

[40]. Zeithaml, Bitner, \& Gremler. 2011. Service Marketing. Fourth Edition. Prentice Hall; exclusive right by Mc Graw - Hill

[41]. Akbar, Muhammad Ridho. (2018). The Effect of Product Quality, Brand Image, and Price Perception on Interest in Buying a Mitsubishi XPander Car in Medan City. Essay. University of Northern Sumatra. Field.

[42]. Andrianto, Hendra Noky. (2013). Effect of Product Quality, Brand Image. Price and Promotion of the Decision to Purchase MPV Type Toyota Kijang Innova in Semarang. Thesis. Diponegoro University. Semarang.

[43]. Budiyanto, I Made. (2016). The Influence of Quality Perception on Purchasing Decisions of Honda Motorcycles in Sidan Village, Kec. Gianyar Kab. Gianyar 2015. Vol 7 No. 2

[44]. C. Mowen, John. Michael Minor. (2012). Consumer behavior. Erlangga Jakarta.

[45]. Cockrill, Antje and Mark MH Goode. (2010). Perceived Price And Price Decay In the DVD Marke. The Journal of Product and Brand Management. 19 (5).

[46]. Durianto, Sugiarto. (2011). Strategies to Conquer the Market through Equity Research and Brand Behavior. PT Gramedia Reader. Jakarta.

[47]. Engel, JF, RD Blackwell, and PW Miniard. (2004). Consumer behavior. Volume 1. Sixth Edition. Binarupa Aksara. Jakara

[48]. Fandy Tjiptono (2011). Marketing Services. Bayumedia Publishing. Yogyakarta.

[49]. Freddy Rangkuti. (2012). Business \& Investment Feasibility Study. Gramedia Main Library. Jakarta.

[50]. Ghozali. (2016). Multivariate Analysis Application with the IBM SPSS Program. Diponegoro University Publisher Agency. Semarang. 
[51]. Greg Joel, James DD Massie, and Jantje L. Sepang. (2014). The Effect of Motivation, Price Perception, and Product Quality on Consumer Interest in Purchasing Yamaha Mio Matic Motorcycle Brands in the City of Manado. EMBA Journal. Vol.2.No.3. Sam Ratulangi University Manado. Manado.

[52]. Hawkins, DI, and Mothersbaugh, DL (2012). Consumer Behavior: Building Marketing Strategy.11th edition. McGraw-Hill, Irwin.

[53]. Istijanto. (2013). Human Resources Research. Gramedia Main Library. Jakarta.

[54]. Jerry C. Olson and Peter J. Paul. (2000). Consumer behavior and marketing strategies. Nine Edition. Salemba four. Jakarta.

[55]. Kotler, Philip and Armstrong, Gary. (2009). Marketing Principles. Issue 9 Volume 1. Erlangga. Jakarta.

[56]. Kotler, Philip and Armstrong, Gary. (2014). Marketing Principles. Issue 12 Volume 1. Erlangga. Jakarta.

[57]. Kotler, Philip and Keller. (2012). Marketing Management 13. Prentice Hall, Inc. New Jersey.

[58]. Kurniawan, Anggoro Dwi and Sri Rahayu Tri Astuti. (2012). Analysis of Product Influence, Promotion, Price and Place on Purchasing Decisions (Study at Semarang Amarta Store). Diponegoro Journal of Management. Vol.1, No.1, Pg. 282-289.

[59]. Kusumaningtyas, Ghaitsa Damararum. (2017). "The Effect of Country of Origin on Quality Perception and Its Impact on Purchase Interest (Study of Prospective Customers Interested in Buying a Toyota Avanza in Jakarta)". Journal of Business Administration, Vol. 43, No.1.

[60]. Lee, Simon and Lawson-Body, Assion. (2011). Perceived Dynamic Princing. Journal of Industrial Management \& Data System.

[61]. Maharama, Arif Reza. (2016). The Effect of Trust, Ease, and Risk Perception on the Decision to Buy a Object Service in Semarang City which is Mediated by Buying Interest as an Intervening Variable. Essay. Sultan Agung Islamic University. Semarang.

[62]. Miranthi, Andra. (2017). Effect of Company Image, Service Quality, and Price Perception on Repurchase Interest through Customer Satisfaction as Intervening Variables. Essay. Diponegoro University. Semarang.

[63]. Munnukka, J. (2011). Customers Intentions as a reflection of price Perceived. Journal of Product \& Brand Management.

[64]. Nagle, TT and Hogan, J. (2016). The Strategy and Tactics of Pricing, a Guide to Growing more Profitably. Prentice Hall.

[65]. Paul, J. Peter and Jerry C. Olson. (2010). Consumer Behavior: Consumer Behavior and Marketing Strategies. Translate. Erlangga Jakarta.

[66]. Putra, Dimas Ariyanto., Moh Hufron., Afi Rachmat Slamet. (2016). The Effect of Brand Image and Product Quality on Purchasing Decisions of Toyota Agya Cars in Malang City. Unisma FE.

[67]. Schiffman and Kanuk (2013). Consumer behavior. Second Edition. Gramedia Index PT. Jakarta.

[68]. Simamora, Bilson. (2011). Win the Market with Effective and Professional Marketing. PT Gramedia Pustaka Utama. Jakarta.
[69]. Sitinjak, Toni. (2001). Market Conduct Strategy through Equity Research and Brand Behavior. PT. Gramedia Reader. Jakarta.

[70]. Sugiyono (2011). Quantitative R\&D qualitative research methods. Afabeta. Bandung.

[71]. Sugiyono (2012). Educational Research Methods Quantitative, Qualitative, and R\&D Approaches. Alfabeta CV. Bandung.

[72]. Sumarwan, U. (2015). Consumer Behavior, Theory and Its Application in Marketing. Ghalia Indonesia. Jakarta.

[73]. Suprapti, Lilik. (2010). Analysis of the Effect of Brand Awareness, Perceived Value, Organizational Association, and Perceived Quality on Consumer Purchasing Decisions. Essay. Diponegoro University's Faculty of Economics. Semarang.

[74]. Umar, Hussein. (2013). Research Methods for Thesis and Thesis. Rajawali. Jakarta. 